\title{
ROLE OF THE LINKING OF METALLIC CENTERS TO MACROMOLECULAR AND OLIGOMERIC SYSTEMS IN THE PYROLYTIC PRODUCTS
}

\author{
CARLOS DÍAZ VALENZUELA**, M. LUISA VALENZUELA ${ }^{B}$, AND , LUIS ZÚNIIGA ${ }^{A}$
}

\author{
${ }^{a}$ Departamento de Química, Facultad de Química. Universidad de Chile. La Palmeras 3425, Nuñoa, casilla 653, Santiago de Chile, Chile, ${ }^{b}$ Departamento de \\ Química Orgánica e Inorgánica. Facultad de Química. Universidad de Oviedo. C/Julián Clavería S/N. Oviedo 33071. España. \\ (Received: 22 October 2007 - Accepted: 25 January 2008)
}

\begin{abstract}
Pyrolysis of the mixtures: $\left[\mathrm{NP}\left(\mathrm{O}_{2} \mathrm{C}_{12} \mathrm{H}_{8}\right)\right]_{\mathrm{n}} / / \mathrm{AuCl}\left(\mathrm{PPh}_{2}\right)$ system (I) $\left[\mathrm{NP}\left(\mathrm{O}_{2} \mathrm{C}_{12} \mathrm{H}_{8}\right)\right]_{0.8}\left[\mathrm{NP}\left(\mathrm{OC}_{6} \mathrm{H}_{4} \mathrm{CH}_{2} \mathrm{CN} \text {. }\{\mathrm{Ru})_{2}\right]_{0.15} \mathrm{NP}_{(\mathrm{OC}} \mathrm{H}_{5}\right) 1 \mathrm{OC}_{6} \mathrm{H}_{4} \mathrm{CH} \mathrm{CN}_{2} \mathrm{CN}$. $\left.[\mathrm{Ru}]_{0.05}\right]_{\mathrm{n}} / /$ ${ }^{t} \mathrm{BuSiMe}{ }_{2} \mathrm{Cl}$ system (II) and $\mathrm{N}_{3} \mathrm{P}_{3}\left[\mathrm{NH}\left(\mathrm{CH}_{2}\right)_{3} \mathrm{Si}(\mathrm{OEt})_{3}\right]_{6} / / \mathrm{N}_{3} \mathrm{P}_{3}\left[\mathrm{OC}_{6} \mathrm{H}_{4} \mathrm{CH}_{2} \mathrm{CN}\right.$. TiCp $\mathrm{Cl}_{2} \mathrm{Cl}_{6}\left(\mathrm{PF}_{6}\right)_{6}$ system (III) were studied in air and at $800{ }^{\circ} \mathrm{C}$, and their products characterized. Nanostructured $\mathrm{Au}$ foams; $\mathrm{RuO}_{2}$ and $\mathrm{Ti}\left(\mathrm{PO}_{3}\right)_{3}$ islands deposited on $\mathrm{SiP}_{2} \mathrm{O}_{7} / \mathrm{P}_{4} \mathrm{O}_{7}$ matrix respectively were obtained. System (I) affords similar results to the pyrolysis of the polyphosphazene having the $\mathrm{AuCl}\left(\mathrm{PPh}_{2}\right)$ coordinated to the polymeric chain which can be attributed to a probable coordination of the Au fragments to the polymer during the heating process. In the system (II) the no presence of metallic nanostructures containing Si was attributed to the absence of Si ultraestructures due to the no cross-linking of the precursor by volatilization of the silicon molecular compound. In the system (III) the ciclic trimer acts each one as template for the formation of mesostructured products remaining separated at the micro level.
\end{abstract}

Keywords: Polyphosphazenes, organometallic metallic, nanostructure.

\section{INTRODUCTION}

Polymers with inorganic elements in the main chain should behave differently at high temperature from their counterpart organic polymers ${ }^{1}$.

Polyphosphazene contains a backbone of alternating phosphorus and nitrogen atoms with two side groups linked to each phosphorus². When the side group contains a coordinating atoms or groups, metallic or organometallic groups can be coordinated to this macromolecular ligand. Previously we have prepared a series of such macromolecular complexes s $^{3-12}$ and determined that their pyrolysis in air and at $800^{\circ} \mathrm{C}$ afford high pyrolytic yields. Most detailed studies of the nature of these products, indicated the formation of metallic nanostructured $\mathrm{M} / \mathrm{MxOy} / \mathrm{Mx}\left(\mathrm{P}_{2} \mathrm{O}_{7}\right) \mathrm{y} / \mathrm{Mx}\left(\mathrm{PO}_{4}\right) \mathrm{y}$ materials ${ }^{13-21}$. When two metals are attached to the same polymeric chain, bimetallic nanostructures are obtained ${ }^{20}$. The formation of such pyrolytic residues has been attributed to the cross-linking of the polymeric chain by the organometallic fragment. As pointed out by Allcock ${ }^{22}$ in the formation of ultraestructures material from pyrolysis of polyphosphazenes, the cross - linking of the polymeric chain during the pyrolysis is a crucial step.

Among others, polyphosphazenes can undergo extensive cross-linking by thermolysis of ion metal or organometallic compound ${ }^{22}$. In these cases the ion metal or organometallic fragments is linked to the polymeric chain, previously to the thermolysis process. Now the question is "must be the organometallic fragment be linked to the polymeric chain to produce an effective crosslinking? To answer this we have performed pyrolysis experiments of several systems consisting of a mixture of organometallic compounds with polymers and oligomers and studied their pyrolytic products. Also we have carried out pyrolysis experiment with mixtures of cyclophosphazene and organometallic compounds. We have previously reported the synthesis and characterization of a series of organometallic derivatives of cyclotriphosphazenes ${ }^{23-25}$.

\section{EXPERIMENTAL}

All reactions were carried out under dinitrogen using standard Schlenk techniques. IR spectra were recorded on an FT-IR Perkin-Elmer 2000 spectrophotometer. Solvents were dried and purified using standard procedures. ${ }^{t} \mathrm{BuSiMe}{ }_{2} \mathrm{Cl}, \mathrm{HOC} \mathrm{H}_{4} \mathrm{CH}_{2} \mathrm{CN}, \mathrm{Ti}(\mathrm{Cp})_{2} \mathrm{Cl}_{2}$ and $\mathrm{NH}_{4} \mathrm{PF}_{6}$ were purchased from Sigma-Aldrich. NMR spectra were recorded on a Bruker AC-300 instrument using $\mathrm{CDCl}_{3}$ as solvent unless otherwise stated. ${ }^{1} \mathrm{H}$ and ${ }^{13} \mathrm{C}\left\{{ }^{1} \mathrm{H}\right\}$ NMR are given in $\delta$ relative to TMS. ${ }^{31} \mathrm{P}\left\{{ }^{1} \mathrm{H}\right\}$ are given in $\delta$ relative to external $85 \%$ aqueous $\mathrm{H}_{3} \mathrm{PO}_{4}$. Constants are in $\mathrm{Hz}$. Thermogravimetric analysis (TGA) and differential scanning calorimetry (DSC) measurements were performed on a Mettler TA 4000 instrument and Mettler DSC 300 differential scanning calorimeter, respectively. The polymer samples were heated at a rate of $10^{\circ} \mathrm{C} /$ min from room temperature to $1000^{\circ} \mathrm{C}$ under constant flow of nitrogen.

SEM photographs were taken with a Philips EM 300 microscope. EDAX (energy dispersive X-ray analysis) microanalysis was performed on a NORAN Instrument micro-probe attached to a JEOL 5410 scanning electron microscope. Images were made on a JEOLSX100 transmission microscope. The finely powered samples were dispersed in n-hexane and dropped on a conventional carbon-wasted copper grid. Then the sample on the grid was dried under a lamp.

The pyrolysis experiments were made by pouring a weighed portion $(0.05-0.15 \mathrm{~g})$ of the respectives mixtures I, II or III into aluminum oxide boats that were placed in a tubular furnace (Lindberg/Blue Oven model STF55346C1) under a flow of air, heating from 25 to $300{ }^{\circ} \mathrm{C}$ and then to $800{ }^{\circ} \mathrm{C}$, and annealing for $2 \mathrm{~h}$. The heating rate was $10^{\circ} \mathrm{C} / \mathrm{min}$ under an air flow of 200 $\mathrm{mL} / \mathrm{min}$.

Preparation of the mixture

Mixture I. The polymer (1) the organometallic $\mathrm{AuCl}\left(\mathrm{PPh}_{2}\right)$ were dissolved in THF $(20 \mathrm{~mL})$, stirred by $12 \mathrm{~h}$. and dried under air at room temperature.

Mixture II . The silicon reactive ${ }^{\mathrm{t}} \mathrm{BuSiMe}{ }_{2} \mathrm{Cl},(0.016 \mathrm{~g})$ in ETOH and the polymer (2) were dissolved in $\mathrm{CH}_{2} \mathrm{Cl}_{2}(20 \mathrm{~mL})$ were stirred for $2 \mathrm{~h}$. Then the solvents were evaporated under vacuum to dried. A yellow with green zones powder was obtained.

Mixture III. The trimers (5) (0.3 g) and (6) $(0.1 \mathrm{~g})$ were dissolved in dichloromethane $(30 \mathrm{~mL})$ and the mixture stirred for $24 \mathrm{~h}$. Then the solvents was evaporated to dried.

The polymers $\left[\mathrm{NP}\left(\mathrm{O}_{2} \mathrm{C}_{12} \mathrm{H}_{8}\right)\right]_{08}\left[\mathrm{NP}\left(\mathrm{OC}_{6} \mathrm{H}_{4} \mathrm{CH}_{2} \mathrm{CN} \text {. }\{\mathrm{Ru}]\right)_{2}\right]_{015} \mathrm{NP}\left(\mathrm{OC}_{6} \mathrm{H}_{5}\right.$ ) $1 \mathrm{OC}_{6} \mathrm{H}_{4} \mathrm{CH}_{2} \mathrm{CN}$. $\left.[\mathrm{Ru}]_{0,05}\right]_{\mathrm{n}}{ }^{7}$ and $\left[\mathrm{NP}\left(\mathrm{O}_{2} \mathrm{C}_{12} \mathrm{H}_{8}\right)\right]_{\mathrm{n}}^{26}$ were prepared as previously reported. The trimer $\mathrm{N}_{3} \mathrm{P}_{3}\left[\mathrm{NH}\left(\mathrm{CH}_{2}\right)_{3} \mathrm{Si}(\mathrm{OEt})_{3}\right]_{6}$ and $\mathrm{N}_{3} \mathrm{P}_{3}\left[\mathrm{OC}_{6} \mathrm{H}_{4} \mathrm{CH}_{2} \mathrm{CN}\right.$. $\left.\mathrm{TiCp}_{2} \mathrm{Cl}\right]_{6}\left(\mathrm{PF}_{6}\right)_{6}$ were prepared using a previously reported methodology ${ }^{23-25}$.

\section{RESULTS AND DISCUSSION}

The systems under study are shown in scheme 1. 


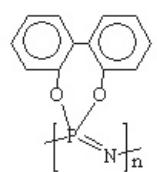

(1)
I

$\mathrm{AuCl}\left(\mathrm{PPh}_{3}\right)$

(2)

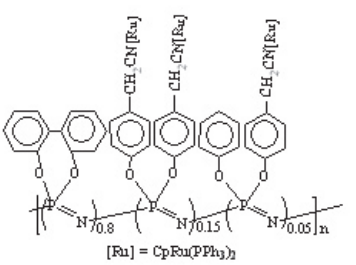

(3)<smiles>[R][R]1([R])=NP([R])([R])=NP([R])(C)=N1</smiles>

$\mathrm{R}=\mathrm{HN}\left(\mathrm{CH}_{2}\right)_{3} \mathrm{Si}(\mathrm{OEt})_{3}$

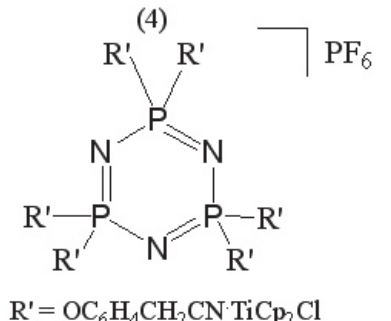

$\mathrm{R}^{\prime}=\mathrm{OC}_{6} \mathrm{H}_{4} \mathrm{CH}_{2} \mathrm{CN} \cdot \mathrm{TiCp}_{2} \mathrm{Cl}$
(5)

(6)

Scheme 1.Schematically representation of the compounds used in the mixtures

\section{System I.}

Previously we have studied the pyrolysis of the polymer containing the organometallic fragment $\mathrm{AuCl}$ anchored to the polymeric chain, of the formula $\left\{\left[\mathrm{NP}\left(\mathrm{O}_{2} \mathrm{C}_{12} \mathrm{M}_{8}\right)\right]_{0.85}\left[\mathrm{NP}\left[\left(\mathrm{OC}_{6} \mathrm{H}_{4} \mathrm{PPh}_{2} \bullet \mathrm{AuCl}\right)_{2}\right]_{011}\right\}_{n}^{19}\right.$.

$\mathrm{Au}$ nanostructured was obtained. From the pyrolysis of the mixture of $\left[\mathrm{NP}\left(\mathrm{O}_{2} \mathrm{C}_{12} \mathrm{H}_{8}\right)\right]_{\mathrm{n}}$ and $\mathrm{AuCl}\left(\mathrm{PPh}_{3}\right)$ a yellow-orange material in $15 \%$ yield was obtained. The XRD patterns can be indexed to cubic $\mathrm{Au}^{19}$. Their XRD is shown in Figure 1a.

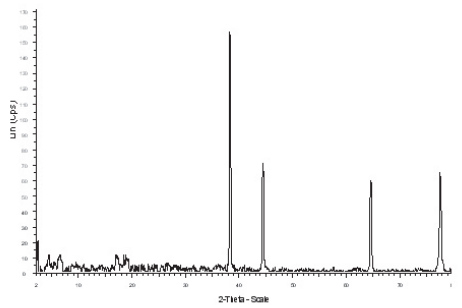

(a)

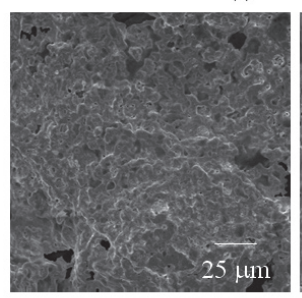

(c)

(d)

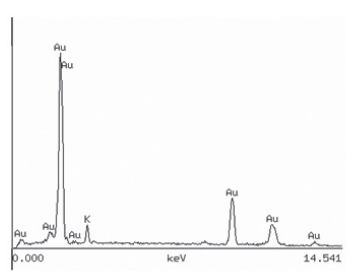

(b)

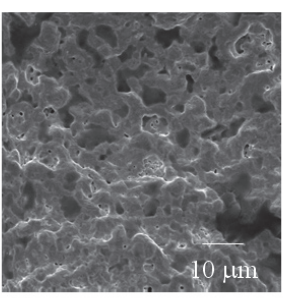

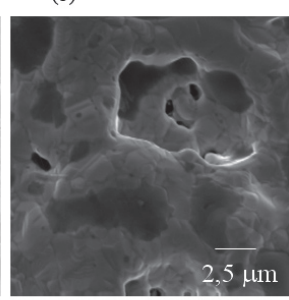

(e)
Figure 1. XRD, EDAX and SEM image of the pyrolytic product from mixture I
Consistently with this, the EDAX analysis showed in Figure $1 \mathrm{~b}$ exhibits only the presence of gold. The morphology of the material, see fig. 1c-e, observed by SEM, shows a metal foam porous 2-D shape. Metal foams are a relatively new class of materials with unique combinations of properties such as high stiffness, low density ${ }^{27-29}$, gas permeability and thermal conductivity. Such materials promise to enable the development of new technologies in areas as diverse as catalysis, fuel cells, hydrogen storage and thermal and acoustical insulation. Preparative method for making metal foams to date have somewhat limited in scope, being the most common, by de-allowing of the bimetallic $\mathrm{Au}_{022} \mathrm{Ag}_{058}{ }^{30,31}$.

Similar metal foam material was obtained by pyrolysis of the polymer ${ }^{19}$ $\left\{\left[\mathrm{NP}\left(\mathrm{O}_{2} \mathrm{C}_{12} \mathrm{H}_{8}\right)\right]_{085}\left[\mathrm{NPOC}_{6} \mathrm{H}_{4} \mathrm{PPh}_{2} \cdot \mathrm{AuCl}\right]_{075}\right\}_{n}$. (7). Thus this can be a relatively simple method to access unprecedented nanostructural monolithic noble metal foams using polyphosphazene as template. As previously discussed for the polymer (7), the formation of Au materials could involve the reduction of the $\mathrm{Au}(\mathrm{I})$ centers by $\mathrm{CO}$ produced by the partial oxidation of the organic matter. The foams nature of the Au materials can be due to the release of volatile nitrogen and chlorine oxides and $\mathrm{CO}_{2}$. As previously pointed out ${ }^{28}$ the formation of metallic foams is determined by the rate of the release of the gases. The solid state combustion synthesis of nanostructured materials is a dynamic and complex process. Ignition of the mixture produces liberation of the metals center from the complex (II), which rapidly join together forming the threedimensional network. Due to the no linking with the polymeric chain as in the polymer (7) the formed phosphorus oxides by oxidation of the polymeric chain, are expelled which preclude their coordination to the growing nanoparticles leading finally to an agglomerated materials as observed by TEM.

In contrast to the formation of $\mathrm{Au}$ from pyrolysis of the organo-gold containing polymer $\left\{\left[\mathrm{NP}\left(\mathrm{O}_{2} \mathrm{C}_{12} \mathrm{H}_{8}\right)\right]_{085}\left[\mathrm{NPOC}_{6} \mathrm{H}_{4} \mathrm{PPh}_{2} \cdot \mathrm{AuCl}\right]_{015}\right\}_{n}$ no discrete nanosize $\mathrm{Au}$ structures were seen by TEM. This can be due to that the nanoparticles are fused together under these conditions to form bulk ${ }^{31,32}$.

\section{System II.}

The incorporation of silicon containing fragments to the polyphosphazene chain could afford, after pyrolysis, metallic nanostructures inside $\mathrm{SiO}_{2}$. However as pointed by Allcock ${ }^{33-35}$ the incorporation of silicon organometallic fragments to the polymers chain is not easy. Another way could be by using the silicon source as a molecular compound as ${ }^{\mathrm{BuSiMe}} \mathrm{Cl}_{2}$. Pyrolysis of a mixture of the polymer $\left[\mathrm{NP}\left(\mathrm{O}_{2} \mathrm{C}_{12} \mathrm{H}_{8}\right)\right]_{0.8}\left[\mathrm{NP}\left(\mathrm{OC}_{6} \mathrm{H}_{4} \mathrm{CH}_{2} \mathrm{CN} \text {. }[\mathrm{Ru}]\right)_{2}\right]_{0.15}\left[\mathrm{NP}\left[\left(\mathrm{OC}_{6} \mathrm{H}_{4} \mathrm{CH}_{2}\right.\right.\right.$ $\left.\mathrm{CN} .[\mathrm{Ru}]]_{0.05}\right]_{\mathrm{n}}$ and ${ }^{\mathrm{B} u S i M e}{ }_{2} \mathrm{Cl}$ under air and at $800^{\circ} \mathrm{C}$ affords a white solid in a $30 \%$ of yield . The XRD spectrum a for the product is shown in figure $2 \mathrm{a}$.

The main diffraction peaks at $2 \theta=27.9^{\circ}, 2 \theta=35,3^{\circ}$ and $2 \theta=54,45^{\circ}$ correspond to tetragonal $\mathrm{RuO}_{2}{ }^{36}$. The broad peak at $2 \theta=18.6^{\circ}$ corresponds to $\mathrm{P}_{4} \mathrm{O}_{7}$ and has been observed in the pyrolysis of other organometallic containing polyphosphazenes ${ }^{13-21}$. This phosphorus oxide acts as solid state stabilizer of the metallic nanoparticles. The presence of mainly $\mathrm{RuO}_{2}$ as product was confirmed by EDAX which exhibits, the presence of phosphorus (small) and $\mathrm{Ru}$ see figure $2 \mathrm{~b}$.

Morphology of the product seen by SEM has a 3-D porous structure. (see fig. $2 \mathrm{c}$-e) However EDAX analysis performed in different zones evidence an inhomogeneous material. For example the zone marked $b$ does not contain ruthenium while the zone a contains $\mathrm{RuO}_{2}$ and $\mathrm{P}_{4} \mathrm{O}_{7}$. It seems to be that under in the conditions of the pyrolysis of the mixture nanostructures of $\mathrm{RuO}_{2}$ embedded in $\mathrm{P}_{4} \mathrm{O}_{7}$ are obtained.

The absence of $\mathrm{Si}$ containing pyrolytic products, evidences that both components of the mixture do not react during the thermolysis, thereby without formation of structures allowing the oxidation of the silicon moieties to give $\mathrm{SiO}_{2}$ (or another product). Then it appears to be that the production of metallic nanoparticles inside $\mathrm{SiO}_{2}$ requires a macromolecular precursor containing covalent linked organosilicon fragments to the polymer. Thus it is likely that during the pyrolysis process probably the molecule containing silicon ${ }^{t} \mathrm{BuSiMe}_{2} \mathrm{Cl}$ is evaporated from the mixture without reacting with the $\mathrm{Ru}$ Polymer. Comparing with the pyrolysis of the pure organometallic polymer $(3)^{21}$, it appears to be that the silicon molecular precursor (4) acts as diluting media of the solid state Ru containing polymer leading to most separated Ru nanostrutures. In the former case most small $\mathrm{RuO}_{2}$ nanoparticles of about 30 nm were observed ${ }^{21}$. 


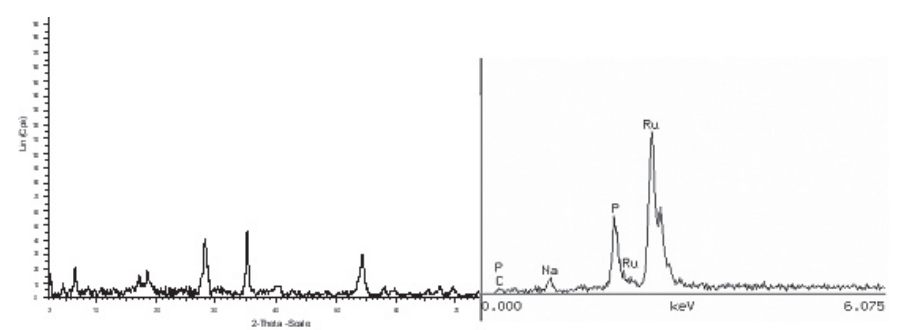

(a)

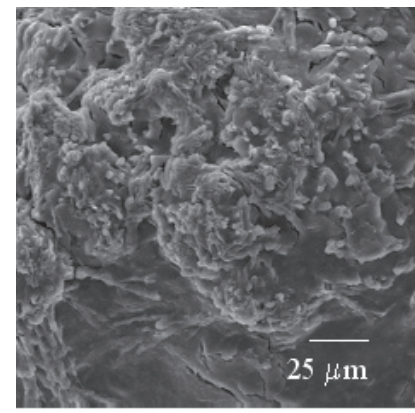

(c)

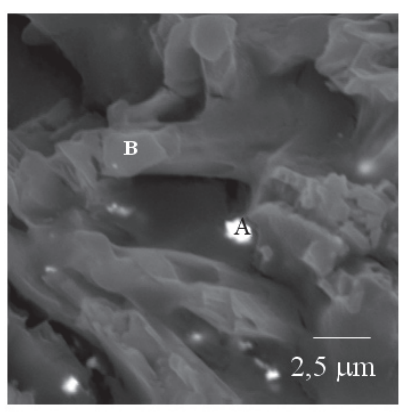

(e) (b)

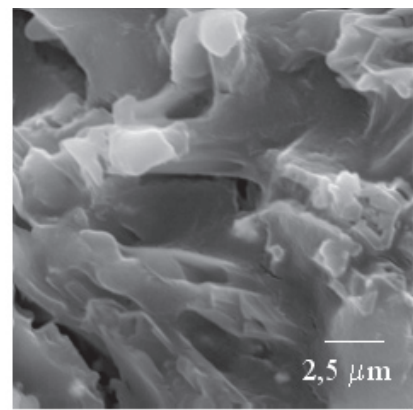

(d)

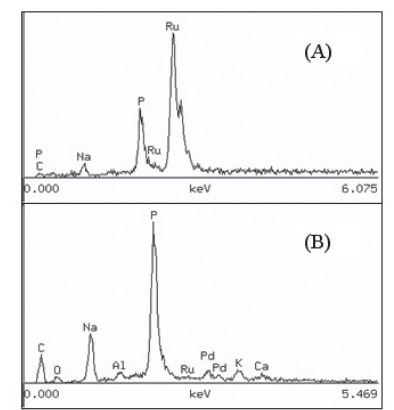

(f)

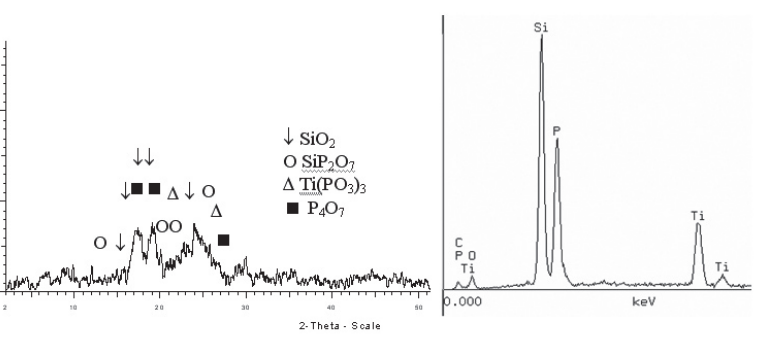

(a)

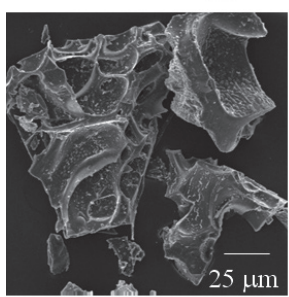

(c)

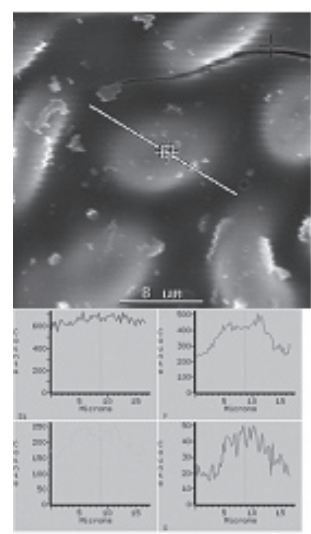

(f) (b)

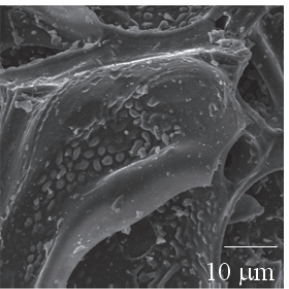

(d)

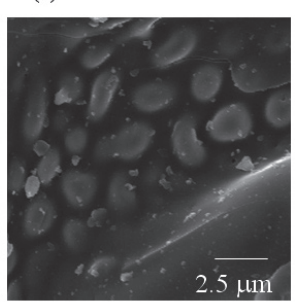

(e)
Figure 2: XRD, (a), EDAX (b) SEM image (c ,d , e) at several magnifications and EDAX (f) (from points A and B from figure (e)).

\section{System III}

Pyrolysis of organometallic derivatives of cyclotriphosphazenes can afford high pyrolytic yields if cyclomatrix are formed ${ }^{38-40}$. In this reaction owing to the high pyrolytic yields of the mixtures, formation of the cyclomatrix are formed but it appears to be that, the respective trimer acts as template for the formation of metallic nanostructures for each one of the metal, Si for (5) and Ti for (6).

In the system III, see scheme 1, the cyclic trimer (5) affords the $\mathrm{Si}$, which after pyrolysis should give $\mathrm{SiO}_{2}$ or $\mathrm{SiP}_{2} \mathrm{O}_{7}$ and the trimer (6) after pyrolysis must give $\mathrm{TiO}_{2}$ (or some Ti phosphate). Pyrolysis of the mixture in air and 800 ${ }^{\circ} \mathrm{C}$ affords a gray solid in $30 \%$ yield. The RDX pattern (see Figure $3 \mathrm{a}$ ) exhibits mainly the diffraction peaks of $\mathrm{SiO}_{2}$ (arrows) $\mathrm{SiP}_{2} \mathrm{O}_{7}$ (circles) and $\mathrm{Ti}\left(\mathrm{PO}_{3}\right)_{3}$ (triangles).

In agree with this the EDAX exhibits the presence of $\mathrm{Si}, \mathrm{P}$ and Ti. Less oxygen content was also observed. The morphology seen by SEM indicated the formation of a non-homogeneous material. From figures $3 \mathrm{~d}$ to $3 \mathrm{e}$ oval shape structures over a continuous plane were observed. In fact a linear sweeping EDAX analysis as shown in figure $3 \mathrm{f}$ indicates clearly a constant content of silicon (probably as $\mathrm{SiP}_{2} \mathrm{O}_{7}$ as evidenced by $\mathrm{RDX}$ ), an increasing of the content of $\mathrm{P}$, Ti and oxygen to cross the zone of the oval nanostructure (in agreement with $\mathrm{Ti}\left(\mathrm{PO}_{3}\right)_{3}$ detected by $\left.\mathrm{RDX}\right)$.

Then a picture of the material macrostructured obtained by pyrolysis of the system III is shown in figure $3 \mathrm{~g}$. It seems to be that during the pyrolysis process the precursor (5) and (6) form nanostructures independent each other i.e. silicon, $\mathrm{SiP}_{2} \mathrm{O}_{7}$ from (5) and $\mathrm{Ti} \mathrm{Ti}\left(\mathrm{PO}_{3}\right)_{3}$ from (6) respectively acting the core phosphazene in both cases as source for the formation of the $\mathrm{PO}_{3}^{-}$as well as $\mathrm{P}_{2} \mathrm{O}_{7}^{4-}$ and also for the formation of the stabilizer $\mathrm{P}_{4} \mathrm{O}_{7}$.
Figure 3: XRD , (a), EDAX, (b), SEM image (c ,d , e), linear EDAX scanning (f) and schematic representation of the nanoparticles from pyrolysis of mixture III, (g).

\section{General Discussion}

It is likely that in the system (I) during the thermolysis process probably the $\mathrm{AuCl}\left(\mathrm{PPh}_{3}\right)$ complex loses $\mathrm{PPh}_{3}$ easily, enabling its coordination to the polymer then giving rise then to a polymer similar to previously reported. This explains the similar products from pyrolysis of the polymer anchored with $\mathrm{Au}$ fragments and the mixture, although it showed with more agglomerate structures.

In the case of the system (II), then a cross-linking ultraestructure containing silicon was not formed. Thus therefore (4) was eliminated by evaporation and not $\mathrm{SiO}_{2}$ was formed. This suggests that the formation of metallic nanostructured material inside $\mathrm{SiO}_{2}$ could be formed only from pyrolysis of organo silicon polyphosphazenes. Preparation of polyphosphazene containing silicon organometallic fragment anchored to the polymeric chain are in course.

In the case of the system III, the two cyclic molecules (5) and (6) do not react, with each other to produce a cross-linked structure. Pyrolysis its seems to proceed independent of each cyclophosphazene giving rise to separate titanium and silicon nanostructures.

The formation of Ti nanostructures inside Si matrix requires probably that the titanium and silicon organometallic fragment are linked covalently to the cyclophosphazene moiety as precursor. 


\section{CONCLUSIONS}

The formation of metallic nanostructures inside $\mathrm{SO}_{2}$ matrix requires polymeric or trimer phosphazenes containing the metallic organometallic fragment linked to it as precursor for the pyrolysis. Metal noble foam materials can be prepared easily from mixtures of polyphosphazenes and organometallic complexes containing the noble metal.

\section{REFERENCES}

1. H.R. Allcock Adv. Mater 6, 106. (1994)

2. M. Gleria, R. De Jaeger Polyphosphazene: a Word Wide Insight; Nova Science Publishers, New York, (2004).

3. C. Díaz $\mathrm{C}$ and M.L. Valenzuela ML in Horizons in Polymers Deveplopments, Bregg RK (ed.), Nova Sience Publishers, NewYork, 2005.

4. C. Díaz and P. Castillo, J Inorg Organomet Polym 11, 183, (2001).

5. C. Díaz, P. Castillo, G.A. Carriedo, P. Gómez-Elipe, F.G. García Alonso Macromol. Chem Phys 203, 1912. (2002).

6. C. Díaz and P. Castillo, Polym Bull, 50, 12, (2003).

7. C. Díaz, m.l. Valenzuela and M. Barbosa, Mater Res Bull. 39, 9, (2004).

8. G.A. Carriedo, F.J. Garcia Alonso, P. Gómez -Elipe, C. Diaz C and N. Yutronic Journal of the Chilean Chemical Society 48, 25 (2003).

9. G.A. Carriedo, F.J. García Alonso, C. Díaz and M.L. Valenzuela Polyhedron 25, 105, (2006).

10. G.A. Carriedo, F.G. García Alonso, P.A. González and P. Gómez Elipe Polyhedron 18, 2853. (1999)

11. G.A. Carriedo, F.G. García Alonso, P.A. González, C. Díaz and N. Yutronic Polyhedron 21, 2579 (2002).

12. G.A. Carriedo, F.J. García Alonso, J.L. García Alvarez, C. Díaz C and N. Yutronic Polyhedron 21, 2587 (2002), and refs therein.

13. C. Díaz and M.L. Valenzuela J Chil Chem Soc 50, 417 (2005).

14. C. Díaz, P. Castillo and M.L. Valenzuela Journal Cluster Science 16, $515,(2005)$.

15. C. Díaz and M.L. Valenzuela J Inorg Organomet Polym Mater 16, 123 (2006).

16. C. Díaz and M.L. Valenzuela Macromolecules 39, 103, (2006).
17. C. Díaz and M.L. Valenzuela J Inorg Organomet Polym Mater 16, 216 (2006).

18. C. Díaz and M.L. Valenzuela J Inorg Organomet Polym Mater 16, 419 (2006).

19. C. Díaz, M.L. Valenzuela , G.A. Carriedo , F.J. García Alonso and A. Presa Polym Bull 57, 920 (2006).

20. C. Díaz and M.L. Valenzuela and N. Yutronic J Inorg Organomet Polym Mater. 17, 577, (2007)

21. C. Díaz, M.L. Valenzuela, E. Spodine Y. Moreno and O.Peña J Inorg Organomet Polym Mater 18, 831, (2007).

22. H.R. Allcock HR, Chem Mater 6, 196 (1996)

23. C. Díaz and I. Izquierdo Polyhedron $18,1479 .(1999)$.

24. C. Díaz, I. Izquierdo, F. Mendizábal and N. Yutronic Inorg Chim Acta 29, 294 (1999)

25. C. Diaz, M. Barbosa and Z. Godoy Polyhedron 23, 1027.(2004).

26. G. A. Carriedo, L. Fernández-Catuxo , F.J. García Alonso , P. GómezElipe and P. González Macromolecules 29, 5320 (1996).

27. A.M. Dodge, J.R. Hayes, J.A. Caro, J. Biener, A.V. Nhamza Adv Eng Mater 8, 835, (2006).

28. B.C. Tappan, M. H. Huynh, M.A. Hiskey, D.E. Chavez, E.P. Luther J.T. Mang and S.F. Son J Am Chem Soc 128, 6589.(2006).

29. I. Banhart, Adv Eng Mater 8, 781 (2004).

30. H. Ehang and A.I. Cooper J Mater Chem 15, 2157 (2005).

31. J. Biener, A.M. Hodge, A.V. Hamza ,L.L. Hsiung and J.H. Satcher Appl Phys 97 1. (2005).

32. Y. . Ding, J. Enlabacher J Am Chem Soc 125, 7772.(2003).

33. H. R. Allcock, D.J. Brennay, J Organomet Chem 341, 231 (1988).

34. H.R. Allcock and S.E. Kuharcik. J Inorg Organomet Polym 6 , (1996).

35. A.R. Allcock and W.D. Coggio Macromolecules 23, 1626 (1990).

36. M.T. Colomer and J.R. Jurado Chem Mater 12 , 923 (2000).

37. M. Gleria and R. De Jaeger, Eds. Applicative Aspects of Cyclophosphazenes , Nova New York, 2004

38. M. Gleria and R. De Jaeger Prog.Polym. Sci. 23, 179, (1998).

39. D.E. Brown , K. Ramachandra , K.R. Carter , and C.W. Allen Macromolecules 34, 2879, (2001)

40. S.J. Maynard, T.R. Sharp, and J.F. Haw Macromolecules 24, 2794 (1991). 